\title{
FINANCIAL RISK MANAGEMENT
}

\author{
Soňa JIRÁSKOVÁ \\ The Armed Forces Academy of General Milan Rastislav Śtefánik, \\ Liptovský Mikuláš, the Slovak Rebublic \\ sona.jiraskova@aos.sk
}

\begin{abstract}
This paper analyses financial risk management at the Ministry of Defence of the Slovak Republic. In its first part, the author defines the basic terms related to risk management, explains the negative consequences of risks and points to the importance of financial risk management. The second part of the paper is concerned with the risk management process at the Ministry of Defence of the Slovak Republic relating to financial management.
\end{abstract}

KEYWORDS: financial resources, financial risk, management system, organization of the public sector, ministry of defence

\section{Introduction}

Life and all human activities involve a lot of existing risks and various crisis situations that can produce detrimental effects. Existence of risks results from the fact that every human activity is associated with potential loss, failure, damage and disruption of stability or security.

Since economy is subject to continuous change, each organisation has to deal with existing risks in real environment and real time. Financial management in organisations is also associated with various risks, which have an impact on running and existence of private and public companies. Management of scarce resources in both types of organisations involves the same rules of economic rationality. Managers in private and public companies have to deal with similar risks, but also the risks that are connected with specific activities and different financing methods.

Even though the public demands reduction of financial resources allocated to public organizations, the services provided to the public must not be restricted (Morong, 2012). Furthermore, the public increasingly calls for transparent and effective use of public funds. Revealing the risks associated with financial management in public institutions is not sufficient. It is necessary to adopt adequate preventive measures, or in other words, to manage the risks using the systems approach.

Risk management is a complex process that involves determination, management, elimination and minimization of uncertain events, which may have an impact on an organization (Smejkal \& Rais, 2003).

Risk management in public organizations should be aimed at adopting the best procedures for identification, evaluation and cost-effective management of risks. Other goals of risk management should include elimination or reduction of risks to acceptable levels and development of systems for monitoring and description of existing and emerging risks, which could have a negative impact on an organization (Oláh \& Šidelský, 2014).

This paper describes the system of financial risk management at the Ministry of Defence of the Slovak Republic. 
2. Financial Risk Management System Adopted at the Ministry of Defence of the Slovak Republic

The public in Slovakia increasingly calls for effective management of public organizations and reduction of risks associated with management of budgetary resources. Public organizations that manage budgetary resources are supposed to obey the act on budget rules, develop a functional system of risk management and respect the "value for money" principle while carrying out public procurement.

The European Union accession procedure requires risk management legislation as an obligatory standard. Therefore, the Ministry of Finance of the Slovak Republic issued the "Regulation on Risk Analysis and Management in Public Administration" in 2006 (Oláh \& Šidelský, 2017). Financial managers in public institutions in the Slovak Republic are expected to adopt measures that will ensure effectiveness of performed activities and eliminate cost inefficiency.

The Act No. 357/2015 Coll. on Financial Control and Audit, which came into force on 1 January 2016, obliges public administration bodies to manage public finances efficiently, purposefully and effectively. Pursuant to this act, risk management process is an essential part of financial management, which the public administration body, including the Ministry of Defence of the Slovak Republic, is supposed to maintain, develop and improve continuously. In order to fulfil this requirement, the ministry adopted an internal regulation on "Financial Risk Management", which has been in force since 2017.

Pursuant to this regulation, financial management is a set of procedures that the Ministry of Defence of the Slovak Republic adopts in risk management, responsible planning, budgeting, use, allocation, accounting and reporting of public finances as well as financial control and internal audits. The aim of financial management is efficient, purposeful and effective use of public finances. Financial and process management includes also risk management as one of the management tools the ministry uses to achieve its goals.

Economic efficiency is the use of public finances for performance of activities or purchase of goods, works or services in appropriate time, amount and quality for the best price. Keeping the costs down is monitored. Financial audits check whether the specified goals were fulfilled by means of the most suitable inputs and the lowest possible costs. Effectiveness is the best possible relationship between costs and outcomes. It is an attempt to achieve the maximum from available resources. Financial managers need to ask themselves a question - "Are the things done properly?" Efficiency can be described as fulfilment of specified goals and achievement of planned results by means of public finances. Managers answer the questions - "Are the things being done properly? Are we achieving the defined goals and results thanks to the financial resources that we are using?". Efficiency is determined by comparison between what should have been done or achieved and what has been done or achieved. Purposefulness is a relationship between the defined purpose of public finances use and the real purpose of their use. The outcome of costs must always be performance of specific usefulness. Financial audits determine whether public finances were used for what they were allocated.

As previously mentioned, financial management of a public organization may involve certain risks that can have a negative effect on its goals and tasks. Risk is the probability of occurrence of an event that will have adverse effects as far as the running, finance, legal matters and fulfilment of goals and tasks are concerned. Negative effects that the risk may exert include:

-threatening or damage to property and rights or uneconomical, inefficient, 
ineffective or purposeless use of public finances,

-non-compliance with generally

binding regulations,

-failure to fulfil the tasks that can threaten achievement of specific objectives,

-performance of ineffective or purposeless activities,

- performance of activities that are beyond existing competencies,

-non-compliance with the required quality.

Other negative influences include threats to information and information systems security and overall damage to organization's good reputation (Oláh \& Šidelský, 2014).

Occurrence of these adverse effects can be avoided by risk management. Risk management is a recurring process of interrelated activities within financial management that are aimed at controlling a possible risk occurrence. The goal of risk management is to decrease the probability of risk occurrence, reduce impacts of the risks and prevent bad results and negative phenomena in entities belonging to the defence sector. Another objective is to avoid discrepancies and fraud.

The responsibility for risk management lies with the executive staff of the defence sector (the Minister of Defence of the Slovak Republic, the state secretary, the head of the Service Office, the Chief of the General Staff of the Slovak Armed Forces), executives who manage individual sections (military units, military offices and installations) and other managerial personnel. It means that the personnel responsible for risk management include both civilian employees as well as professional soldiers who manage the defence sector.

Every employee (not only the executive staff), who identified a major risk that could have a substantial impact on public finances and fulfilment of tasks and goals of the Ministry of Defence of the Slovak Republic, is obliged to immediately advise the head of a particular section of the risk occurrence. This employee adequately responds to existing or detected risks and immediately advises the executive staff of the risk occurrence in a written or oral form.

\section{Financial Risk Management} Process at the Ministry of Defence of the Slovak Republic

In terms of theory, risk management is a systematic application of managerial policy, procedures and experience in the following activities (Belan \& Mišík, 2016):

- communication, consultations,

- detecting causality,

-identification, analysis, assessment, treatment, monitoring and reviewing of risks.

According to the internal regulation, the risk management process at the Ministry of Defence of the Slovak Republic consists of the following steps:

-identification of risks,

- analysis and assessment of risks,

-treatment of risks,

- monitoring of risks,

-assessment and verification of the risk management process.

Risk identification determines to what extent the fulfilment of objectives is endangered due to uncertainties resulting from possible negative effects. This step includes reports and notifications of risks that provide information on the risk source and bearer. This information is essential for adoption of adequate measures. Risk identification is done by means of various methods and it is based on expert judgement and knowledge of the field in which the risk has been identified. The outcome of this step is description of the risk, which is then recorded in the risk register.

Risk analysis and assessment is a prerequisite for making decisions on how to treat the risk. It is performed according to widely used models and procedures or their combination (for example, market research, search and modelling of real possibilities, 
statistical inference, SWOT analysis, fault tree analysis, etc.). Risk assessment provides information on how serious the risk is, whether it can be accepted or if it is necessary to adopt measures to treat it. Financial risk management uses a threelevel scale to assess the risks. The scale includes the following criteria:

a) likelihood (frequency):

- low level 1 - occurrence of the risk event is rare or possible,

- medium level 2 - occurrence of the risk is possible and the risk event frequently recurs,

- high level 3 -occurrence of the risk is highly likely or even certain, the risk event often recurs,

b) consequence:

- low level 1 - consequences are not serious and financial loss is minimal; the consequences have no or only a negligible impact on the ministry's objectives; however, if appropriate measures are not adopted, these risks may bring about more substantial and cumulative effects,

- medium level 2 - risks can have more significant effects on fulfilment of the ministry's objectives; they usually occur irregularly and they are not easily predictable,

- high level 3 - risks may enormously influence accomplishment of the ministry's objectives and they can cause huge financial losses or other kinds of losses; they usually occur irregularly and they are not easily predictable.

The outcome of this phase is determination of a significance level of the risk, which is recorded in a risk register, risk catalogue and a risk map.

Risk treatment means adoption of measures in order to minimize the occurrence or reduce the influence of a possible risk. It is the process of selecting and implementing of measures based on evaluation of alternative appropriate actions (avoiding the risk by adopting other measures, removing the risk source, reduction of likelihood and direct consequences of the risk, passing on the risk to another entity, e. g. by means of insurance, accepting the residual risk). In risk treatment, much attention has to paid to the medium (points 3 to 4 ) and, especially, high (points 6 to 9) significance level of the risk.

Risk mitigation measures must be adopted on the basis of estimated costeffectiveness. Risks at low significance level that do not require adoption of any measures are deemed to be acceptable.

Risk monitoring and assessment is the flow of information on the risk management results at a particular organizational section a risk owner. It includes submission of evaluation materials, which contain information about control activities focused on risk management, adoption of mitigation measures and assessment of their effectiveness. The output of this step is the information on treatment of serious risks in strategic and evaluation materials, which is presented at sessions of chiefs of individual sections and executive staff of the defence sector, and the internal audit reports.

\section{Conclusion}

Risk management is becoming increasingly important also in management of public organizations. Professional soldiers working as managers have to be competent in many areas. They are supposed to have military knowledge as well as knowledge of public finance management (Petrufová, 2014). Therefore, there has to be a methodical basis that professional soldiers can rely on in the risk management process.

The Ministry of Defence of the Slovak Republic responded flexibly to this requirement by adopting an internal regulation on financial risk management. Establishment of the mandatory administrative framework for financial risk management should enhance the quality of management in internal organizational 
sections of the defence sector and support the cost-efficient and effective budgetary policy, maintenance of financial and budgetary discipline and rational spending of public funds for ensuring national security.

Methodical instructions concerning risk management in public organizations (including the defence sector) should include the procedures that would, according to Oláh and Šidelský (2017), point to management of the risks that are not sufficiently reflected in the regulations and directives currently issued by the Ministry of Finance of the Slovak Republic. These risks include:

- collusion risks,

-risks resulting from conflicts of interests,

- fraud risks,

- secondary risks,

- residual risks.

\section{REFERENCES}

Belan, L', \& Mišík, J. (2016). Manažérstvo bezpečnostného rizika, Žilina: Žilinská univerzita v Žiline, 134.

Ministry of Defense of the Slovak Republic. (2017). Directive of the Ministry of Defense of the Slovak Republic no. 7/2017 on risk management in the field of financial management, Bratislava: Author.

Morong, S. (2012). Limity obranných zdrojov Slovenskej republiky a kolektívna bezpečnost', Bezpečné Slovensko a Európska únia : zborník príspevkov zo 6. medzinárodnej vedeckej konferencie, Košice: Vysoká škola bezpečnostného manažérstva v Košiciach, 318-327.

Oláh, M., \& Šidelský, L. (2014). Riadenie rizika a úloha kontroly ako nástroja pre ich riešenie vo verejnej správe, Verejná správa a regionálny rozvoj, roč.10, č.1, 7-16.

Oláh, M., \& Šidelský, L. (2017). Predpoklady na väčšie zainteresovanie manažmentu pri riešení riadenia rizík vo verejnej správe, Scientific Journal Public Administration and regional developement, Vol. 13, Issue 1, 53-65.

Petrufová, M. (2014). Problems of manager competencies and teaching management in the military, Revista Academiei Forţelor Terestre, Vol. 19, Issue 2, 194-201.

Smejkal, V., \& Rais, K. (2003). Řizení rizik, Praha: Grada Publishing, 272.

The National Council of the Slovak Republic. (2015). The Act No. 357/2015 Coll. on Financial Control and Audit. Bratislava. 